\title{
THE MAKING OF THE TURKISH FINANCIAL CRISIS
}

\author{
Y_lmaz Akyüz and Korkut Boratav*
}

There can be little doubt that at the turn of the century the Turkish economy was in need of an urgent stabilization in order to halt a treacherous process of high and volatile inflation, unsustainable public debt accumulation, and increasing financial fragility, resulting from irresponsible policies and lack of fiscal discipline that had been endemic under various governments since the early 1980s. However, the stabilization program formulated and launched with strong support from the IMF failed to deliver its promises, plunging the economy into an unprecedented crisis, in large part because of serious shortcomings in its design as well as in crisis intervention which appears to have drawn no useful lessons from the recent bouts of crises in emerging markets.

\section{Introduction}

In December 1999 the Turkish government launched an exchange-rate-based stabilization program with the support of the Bretton Woods Institutions in order to bring down inflation and check what looked like an unsustainable process of public debt accumulation. The program appeared to be on course in the subsequent nine months, enjoying wide public confidence and support as well as gaining praise from IMF officials. However, it started running into problems in Autumn 2000, necessitating a relatively large IMF bailout to keep it on course. After a few months of muddling through it became clear that the program was not viable, and in the face of massive attacks on the currency and rapid exit of capital, the currency peg had to be abandoned in February 2001 and replaced by a regime of free floating, again on advice from the IMF. As in most other episodes of financial crisis the currency overshot, interest rates rose sharply and the economy contracted at an unprecedented rate. After another bailout package from the IMF, financial and currency markets stabilized towards the end of the year, but employment and economic activity remained depressed. Just as the bust in the financial cycle

\footnotetext{
* The authors are Director, Division on Globalization and Development Strategies, UNCTAD, and Professor of Economics, University of Ankara, respectively. An earlier draft of this paper was presented to a conference on "Financialization of the Global Economy", PERI, University of Massachusetts, December 7-9, Amherst, Mass. The opinions expressed in this paper and the designations and terminology employed are those of the authors and do not necessarily reflect the views of UNCTAD. The authors are grateful to Andrew Cornford and Richard KozulWright for comments and suggestions.
} 
came much earlier than in most other episodes of financial crisis, recovery also appears to be delayed.

What went wrong? The Turkish crisis has a number of features common to crises in emerging markets that implemented exchange-rate-based stabilization programs. Such programs typically use the exchange rate as a credible anchor for inflationary expectations, often leading to currency appreciations and relying on capital inflows attracted by arbitrage opportunities to finance growing external deficits. The consequent build-up of external financial vulnerability eventually gives rise to expectations of sharp currency depreciations and a rapid exit of capital, resulting in overshooting of the exchange rate in the opposite direction and hikes in interest rates. Through such a boom-bust financial cycle, some countries (e.g. Mexico, Brazil and Russia) have succeeded in overcoming their chronic price instability and avoiding a return of rapid inflation, despite the collapse of their currencies and the external adjustment necessitated by the crisis. The Turkish program initially followed a similar path, but ran into difficulties at a much earlier stage of the disinflation process, forcing policy-makers to abandon the peg and setting of a sharp economic downturn in the context of a high inflation.

The difficulties arose largely because the program was launched in the face of structural problems and fragilities on many fronts, notably in public finances and the banking sector. In particular, the banking sector was heavily dependent for its earnings on high-yielding T-bills associated with rapid inflation, and was thus highly vulnerable to disinflation. Consequently, there emerged an inconsistency in policy since much of the fiscal adjustment was predicated on declines in the very nominal and real interest rates on which many banks depended for their viability. Furthermore, while the program incorporated a preannounced exit from the crawling peg after 18 months, it failed to meet its inflation targets despite full implementation of its monetary and fiscal policy targets. Thus, what initially looked like a strength of the program backfired, as persistently high inflation, together with widening current account deficits, fed into expectations of a sharp depreciation of the currency. These shortcomings in the design of the program, rather than a failure to implement it, are the main reason why the boom in capital inflows was much shorter in Turkey than in most other experiments with exchange-rate-based stabilization, and why the crisis broke out before inflation was brought under control.

It should also be recognized that recent bouts of liquidity crises in emerging markets have significantly eroded the confidence of international investors in the sustainability of such soft pegs, so that 
rapid exits tend to be triggered at the first signs of trouble. In this sense the Turkish experience also suggests that the chances of successful disinflation by means of an exchange-rate anchor may now be significantly lower. Indeed, the behaviour of private capital flows to emerging markets in the current global downturn shows that, unlike in the first half of the 1990s, international investors have become much more nervous in raising their exposure to emerging markets despite falling investment opportunities in the major industrial countries (UNCTAD 2001a).

That the Turkish crisis has proved much deeper than most crises in emerging markets is not only due to problems in the design of the stabilization program. Equally important is mismanagement in crisis intervention, which had been premised, as in most other emerging markets, on restoring confidence, maintaining capital-account convertibility, and meeting the demands of creditors through fiscal and monetary tightening. While the implementation of the program had created a trade-off between public and private finances, abandoning the peg and moving to free floating under full capital account convertibility and extensive dollarization aggravated the difficulties of both public and private sectors. The collapse of the currency hit hard those sectors with high exposure to exchange rate risks which the earlier peg had encouraged. Public finances were squeezed from rising external and domestic debt servicing obligations due to the collapse of the currency and the hike in interest rates. Fiscal austerity and monetary tightening have served to deepen recession, and even growth in exports has remained relatively modest despite the sharp depreciation of the currency because of disruptions in the credit and supply systems, in very much the same way as in the earlier phase of the crisis in East Asia. Various packages of legislation passed in order to initiate structural reforms in the public and private sectors failed to restore confidence, while their initial impact was to add to stagflationary pressures. Furthermore, the external economic environment deteriorated further with the downturn in the major industrial countries and the events of 11 September. However, these events have also helped Turkey in mobilizing unprecedented amounts of external support from the IMF due the strategic position that the country occupies in the United States' "war against terrorism". Despite four IMF bailout packages in two years, however, the economy shrunk at an unprecedented rate of some 9.5 per cent in 2001, and prospects for a strong recovery are highly uncertain.

\section{The build up of imbalances: Inflation, debt and capital flows}


Many of the imbalances and fragilities that characterised the Turkish economy at the turn of the century had their origin in the policies pursued in the previous two decades. Turkey started the 1980s with a stabilization-cum-liberalization experiment under a military rule in response to a deep debt and balance-of-payments crisis beginning in late 1970s. The program enjoyed some initial success and was widely praised as an example of successful transition from an inward to an outward development strategy and generously supported by multilateral institutions. ${ }^{2}$ Inflation was brought down from three digit levels in 1980 to some 30 per cent in the subsequent two years, and the cost of disinflation in terms of foregone output was relatively small, with GDP contracting by some 2 per cent in 1980 . This was followed by an export-led growth, with manufacturing exports growing at double-digit rates, supported by favourable exchange rates and massive incentives in the form of tax rebates. The average GDP growth rate stayed above 6 per cent per annum during 1983-1987.

Initially the program achieved a strong macroeconomic adjustment. The current account deficit was halved during 1981-1982 from a level of 5 per cent of GDP at the beginning of the decade, while the public sector borrowing requirement (PSBR) fell from around 10 per cent of GNP to less than 4 per cent. However, macroeconomic imbalances reappeared after 1987. While the current account registered either a surplus or a small deficit, the PSBR reached almost 10 per cent of GNP at the end of the 1980s. Again, inflation accelerated rapidly from 1987 onwards, exceeding on average, 60 per cent during the last three years of the decade.

Two factors appear to have played a significant role in the re-emergence fiscal imbalances and the acceleration of inflation. First, the macroeconomic adjustment and export push had been achieved in large part through drastic cuts in real wages and reduced support to agricultural producers both during the military regime of 1980-1983 and the subsequent civilian government that came to power in a highly

\footnotetext{
${ }^{2}$ For various aspects of this experience see a collection of papers in Aricanli and Rodrik (1990).
} 
repressive political environment. The return to hotly contested elections and parliamentary democracy after 1987 led to popular demands and compensatory policies (Boratav and Yeldan, 2001). Second, contrary to orthodox rhetoric on sequencing, domestic financial markets were liberalized before fiscal discipline had been secured and inflation brought under control. Deregulation of interest rates and the shift from central bank financing to direct security issues raised the cost of financing of public sector deficits: even before the acceleration of inflation in 1988, interest rates on government paper exceeded the rate of inflation by between 10 and 20 percentage points. As a result, public domestic debt and interest payments as a proportion of GDP started to rise from mid-1980s.

Thus, towards the end of the decade the economy had run out of steam and public sector deficits and inflation had come back with full force. The policy response was to liberalize fully the capital account in 1989. The foreign exchange regime had already been liberalized in certain respects in 1984, bringing current account convertibility and allowing residents to hold foreign currency deposits in domestic banks and to engage in specified foreign exchange transactions. New legislation in 1989 effectively lifted restrictions on inward and outward financial transactions by residents and non-residents alike, thereby exposing the economy to the whims of international capital flows.

An implicit objective of capital-account liberalization was to facilitate the financing of public sector deficits without crowding-out private investment. However, the outcome was to aggravate the fiscal problem, forcing the government to pay interest rates incorporating a higher spread compared to the safer dollar assets which became easily accessible even for small savers. During the 1990s interest rates on government debt exceeded the inflation rate, on average, by more than 30 percentage points. With inflation averaging some 75 per cent, this meant a real rate of interest of more than 17 per cent (table 1). Two factors appear to have played a crucial role in pushing up the rate of interest on government debt. First, dollarization reduced the transaction costs of entry and exit into foreign assets, raising their net return. Second, instability of the inflation rate raised the risk of assets denominated in domestic currencies, raising the spread; during the decade as a whole, the standard deviation of annual average rate of inflation was 15 percentage points. These factors accelerated the currency substitution, raising the share of foreign exchange deposits held by residents in total bank deposits from 25 per cent 
in 1990 to 43 per cent in 1999. The rate of interest earned on dollar deposits rose rapidly, reaching double digit figures after 1997. 
Table 1

TURKEY: MACROECONOMIC INDICATORS, 1990-2000

\begin{tabular}{|c|c|c|c|c|c|c|c|c|c|c|c|}
\hline & 1990 & 1991 & 1992 & 1993 & 1994 & 1995 & 1996 & 1997 & 1998 & 1999 & 2000 \\
\hline GDP growth rate & 9.3 & 0.9 & 6.0 & 8.0 & -5.5 & 7.2 & 7.0 & 7.5 & 3.1 & -4.7 & 7.4 \\
\hline CPI (per cent change) & 60.3 & 66.0 & 70.1 & 66.1 & 106.3 & 93.7 & 82.3 & 85.7 & 84.6 & 64.9 & 54.9 \\
\hline Interest rates $^{a}$ & 51.9 & 109.6 & 97.8 & 90.3 & 150.6 & 136.3 & 143.6 & 119.2 & 115.7 & 96.6 & 37.0 \\
\hline Exchange rate ${ }^{b}$ & 22.9 & 60.0 & 64.6 & 59.8 & 171.6 & 53.6 & 77.7 & 86.5 & 71.8 & 60.9 & 49.0 \\
\hline $\begin{array}{l}\text { Public sector balance } \\
\text { of which: } \\
\text { primary balance }\end{array}$ & -7.6 & -11.3 & -12.4 & -13.1 & -10.2 & -6.4 & -13.2 & -13.1 & -15.9 & -24.5 & -19.3 \\
\hline $\begin{array}{l}\text { Net debt of the public sector } \\
\text { of which: } \\
\text { net domestic debt }\end{array}$ & 28.8 & 35.2 & 35.7 & 35.1 & 44.7 & 41.3 & 46.5 & 42.9 & 44.5 & 61.7 & 59.0 \\
\hline Current account deficit ${ }^{c}$ & -1.7 & 0.1 & -0.6 & -3.6 & 2.2 & -1.5 & -1.3 & -1.3 & 1.1 & -0.9 & -4.9 \\
\hline Gross external debt ${ }^{c}$ & 32.6 & 33.0 & 34.8 & 36.9 & 50.1 & 42.4 & 45.3 & 47.0 & 51.2 & 55.6 & 57.1 \\
\hline Foreign deposits & & & & & & & & & & & \\
\hline Billions of dollars & 7.4 & 10.2 & 12.4 & 13.7 & 15.6 & 20.5 & 24.4 & 26.8 & 30.6 & 34.1 & 37.7 \\
\hline Per cent of total deposits & 24.9 & 31.9 & 34.9 & 38.0 & 47.4 & 47.6 & 44.5 & 42.1 & 42.1 & 41.7 & 43.5 \\
\hline
\end{tabular}

Source: IMF (2000a and 2001c); OECD (2001); Central Bank of Turkey, Quarterly Bulletin, various issues; and Türkiye'nin Güçlü Ekonomiye Geçis Programi, 2001, Undersecretary of Treasury.

a From 1990 to 1991: overnight interest rates, annual simple basis. From 1992 to 1997: Treasury bills, 3-months or close to maturity realised at Treasury auctions, compounded and weighted by net sales. From 1998 onwards: Treasury bills, up to 3 months traded in the secondary market, compounded and weighted by the volumes.

b Per cent change in the lira/\$ exchange rate.

c Per cent of GDP.

The outcome was a rapid build up of public debt and the emergence of a financial system which came to depend on arbitrage margins offered by high rates on government debt in comparison with international borrowing and domestic deposits, including forex deposits, at the cost of large currency risks. Government was increasingly engaged in Ponzi financing whereby rising interest payments could only be met by issuing new debt instruments. Thus, while interest payments on domestic debt absorbed less than 20 per cent of tax revenues at the end of the 1980s, this proportion rose steadily throughout 
the 1990s exceeding 75 per cent at the end of the decade. The PSBR rose rapidly during the same period reaching, on IMF definition, 24 per cent of GDP. While primary deficits in the first half of the decade played an important role in pushing up the PSBR, interest payments became by far the most important component of fiscal deficits in the second half of the 1990s. New public debt instruments (bonds and bills) issued to meet budget deficits rose from less than 6 per cent GDP at the beginning of the 1990 s to almost 40 per cent at the end of the decade.

Like many other emerging markets with open capital accounts, Turkish financial markets, interest rates and exchange rates went through large swings during the decade, associated with boombust cycles in international capital flows. The increased financial instability was almost fully mirrored by ups and downs in economic activity. From 1990 to 2001, while the average growth rate of GDP was around 3 per cent, its standard deviation was twice as large, reaching 6 percentage points. Such a degree of instability was unprecedented, not seen even during the turbulent decade of the 1970s when the economy faced a series of large positive and negative external shocks due to sharp changes in workers' remittances and oil prices. Increased fluctuations in economic activity have been accompanied by greater instability in fixed capital formation, with attendant consequences for the long-term growth potential of the economy. ${ }^{3}$

The initial boom coincided with the surge in capital inflows to Latin America in the early 1990s which eventually culminated in the Mexican crisis of 1994-1995. Between 1990 and 1993, cumulative

\footnotetext{
${ }^{3}$ For instance during the last cycle, fixed investment fell by some 16 per cent in 1999 , then rose by 17 per cent during the boom of 2000, and fell by as much as 32 per cent in 2001.
} 
net capital inflows by non-residents reached $\$ 25$ billion while the current account deficit remained below $\$ 10$ billion (table 2). ${ }^{4}$ Only a small part of the surplus was absorbed by increases in reserves while a large proportion was used to finance capital outflows by residents who apparently took the opportunity offered by the new capital account regime to diversify their

\footnotetext{
${ }^{4}$ The classifications and definitions of capital flows used here and in tables 2 and 3 follow the conventions used in the IMF Balance of Payments Statistics. Capital inflow refers to the acquisition of domestic assets by non-residents. Sales of domestic assets are defined as a negative capital inflow. Thus the term net capital inflows denotes acquisition minus sales of domestic assets by non-residents. Capital outflow refers to the acquisition of foreign assets by residents. Sales of foreign assets are defined as a negative capital outflow. Net capital outflows denote acquisitions minus sales of foreign assets by residents. Net capital flow refers to net capital inflows less net capital outflows as defined above. It is positive when net inflows exceed net outflows. For a further discussion of these concepts see UNCTAD (1999, box 5.1, p. 100).
} 
Table 2

\section{CAPITAL FLOWS AND BALANCE OF PAYMENTS}

(Millions of dollars)

\begin{tabular}{|c|c|c|c|c|c|}
\hline & $\begin{array}{c}\text { Net capital } \\
\text { inflows }\end{array}$ & $\begin{array}{c}\text { Net capital } \\
\text { outflows }\end{array}$ & $\begin{array}{l}\text { Current } \\
\text { account }\end{array}$ & $\begin{array}{c}\text { Errors and } \\
\text { omissions }\end{array}$ & $\begin{array}{c}\text { Changes in } \\
\text { reserves }\end{array}$ \\
\hline \multicolumn{6}{|l|}{ Cumulative } \\
\hline 1990-1993 & 24536 & -10333 & -9782 & -2932 & -1489 \\
\hline 1994 & -6259 & 2409 & 2631 & 1766 & -547 \\
\hline \multicolumn{6}{|l|}{ Swing } \\
\hline 1993-1994 & -19090 & 6277 & 9064 & 3988 & -239 \\
\hline \multicolumn{6}{|l|}{ Cumulative } \\
\hline 1995-1997 & 26173 & -4832 & -7454 & -2021 & -12866 \\
\hline 1998 & 3677 & -3453 & 1984 & -1991 & -217 \\
\hline \multicolumn{6}{|l|}{ Swing } \\
\hline 1997-1998 & -7623 & -742 & 4663 & 603 & 3099 \\
\hline \multicolumn{6}{|l|}{ Cumulative } \\
\hline 1980-1989 & 15529 & -3471 & -10408 & 2910 & -4560 \\
\hline \multicolumn{6}{|l|}{ Cumulative } \\
\hline 1990-2000 & 74654 & -23785 & -23746 & -5898 & -21226 \\
\hline
\end{tabular}

Source: IMF, Balance of Payments Statistics (various years).

a Minus sign indicates increase.

portfolios by acquiring assets abroad. As expected, the boom in capital inflows was associated with a real appreciation of the currency, a strong recovery during 1992-1993 and widening current account deficits. During 1990-1993, annual inflation averaged around 65 per cent, the annual increase in the dollar against the lira averaged 52 per cent, while the interest rate on short-term government debt averaged over 85 per cent (table 1). The boom was followed by a bust in 1994, about a year before the outbreak of the Mexican crisis, with a rapid reversal of net capital inflows. The swing in net capital inflows amounted to some $\$ 19$ billion, or 12 per cent of GDP. The downgrading of the Turkish credit rating in international markets as well as efforts by the 


\section{Table 3}

\section{BOOM AND BUST IN CAPITAL FLOWS IN THE TURKISH CRISIS}

(Millions of dollars)

January-October $2000 \quad$ November 2000-September 2001

$\begin{array}{lrr}\text { Net capital inflows } & 15179 & -12416 \\ \text { Net capital outflows } & -2707 & -1247 \\ \text { Total net capital flows }^{a} & 12474 & -13663 \\ \text { Changes in reserves }^{a} & -2324 & 16585 \\ \text { Errors and omissions }_{\text {Current account balance }} & -2550 & -3215 \\ & -7598 & 293\end{array}$

Source: Central Bank of Turkey.

a Includes IMF credits and changes in official reserves. Minus sign in dicates increase.

government to impose lower interest rates on banks participating in T-bill auctions played an important role in triggering the reversal of capital flows. The dollar overshot against the Turkish lira, inflation reached three digit levels, and interest rates rocketed to exceed 150 per cent. The economy went into a deep recession in 1994 and the current account swung into surplus as a result of massive cuts in imports.

As in Mexico the downturn was short-lived and the recovery rapid. Capital flows returned during 1995-1997 when the economy enjoyed three successive years of growth in excess of 7 per cent. During that period currency appreciation was generally avoided as the Central Bank of Turkey (CBT) effectively pursued a policy of stabilising the real exchange rate. This together with the initial real depreciation of the lira meant a sharp recovery in exports, which helped to keep the current account at sustainable levels despite rapid growth. As net capital outflows by residents also slowed down, much of the capital inflows was absorbed by increases in international reserves (table 2). Such flows were attracted in large part by short-term arbitrage opportunities as interest rates on public debt remained 
well above the rate of inflation and the rate of depreciation of the nominal exchange rate. However, capital inflows slowed sharply after the East Asian crisis, falling from 5.8 per cent of GNP in 1997 to 1.8 per cent in 1998. Growth was halved compared to the previous three years and the current account went into surplus. The fallout from the Russian crisis and a devastating earthquake in 1999 pushed the economy into a deep recession with GDP falling close to 5 per cent. While a currency crisis was averted over the turbulent years of 1998-1999, the banking sector felt the squeeze from tightened external financial conditions and contraction in economic activity. Eight insolvent banks had to be taken over by the public Saving Deposit Insurance Fund (SDIF), in accordance with the full insurance granted to deposits after the 1994 crisis, thereby adding considerably to public debt and deficits.

Thus, on the eve of the launching of the 1999 stabilization program, the Turkish economy was undergoing a sharp contraction and there were serious difficulties in the banking system. By contrast the external sector looked relatively healthy. The balance of payments position was sustainable and the currency did not seem to be out of line with the underlying fundamentals as the earlier appreciation had to a large extent been corrected by the sharp decline in 1994, and the CBT effectively followed a policy of an adjustable peg designed to prevent a significant real appreciation of the lira. This was also the view expressed in an IMF staff report issued on the eve of the stabilization program: "Taken as a whole, the results suggest that the lira could appreciate by about 10 per cent from its 1998 average while remaining consistent with a sustainable current account deficit. ... using the criterion of stabilizing the net debt-to GDP ratio, the analysis in this chapter suggests that Turkey's real exchange rate was 'undervalued' by about 10 per cent in 1998.' ${ }^{15}$ Presumably this 'undervaluation' continued throughout 1999 since the nominal exchange rate was generally kept in line with inflation.

However, domestic imbalances were serious. Government debt had grown rapidly over the preceding decade exceeding 60 per cent of GDP at the end of 1999, and two-thirds of this was

\footnotetext{
${ }^{5}$ IMF (2000a, p. 68). After the outbreak of the crisis, however, an IMF official claimed that "the low deficit [in 1999] was the result of a deep recession caused by extremely high domestic interest rates brought on by economic mismanagement and lack of adequate access to international capital markets", Cottarelli (2001).
} 
domestic debt. The PSBR was over 24 per cent of GDP, with 22 per cent taken by interest payments and 2 per cent by primary deficits. With interest rates exceeding inflation by more than 


\section{TURKISH STABILIZATION AND CRISIS: MACROECONOMIC TARGETS AND PERFORMANCE}

\begin{tabular}{|c|c|c|c|c|c|c|}
\hline & \multirow[t]{2}{*}{1999} & \multicolumn{2}{|c|}{2000} & \multicolumn{3}{|c|}{2001} \\
\hline & & target & perf. & & rget $^{a}$ & perf. \\
\hline \multicolumn{7}{|l|}{ Real sector } \\
\hline GNP growth rate & -6.1 & 5 to 5.5 & 6.1 & -3.0 & $(5$ to 6$)$ & -9.4 \\
\hline WPI inflation ${ }^{b}$ & 62.9 & 20.0 & 32.7 & 57.6 & (10 to 12$)$ & 88.6 \\
\hline CPI inflation ${ }^{b}$ & 68.8 & 25.0 & 39.0 & 52.5 & (10 to 12$)$ & 68.5 \\
\hline \multicolumn{7}{|c|}{ Average T-bill interest rate } \\
\hline Nominal & 106.2 & - & 38.0 & 81.1 & & 100.4 \\
\hline Real (backward looking) & 25.2 & - & -11.4 & 23.7 & & - \\
\hline Real (forward looking) & 32.0 & - & -6.5 & 36.4 & & - \\
\hline \multicolumn{7}{|c|}{ Consolidated public sector ${ }^{c}$} \\
\hline Primary balance & -2.0 & 2.2 & 2.8 & 5.5 & $(5.0)$ & 5.5 \\
\hline Net interest payments & 22.1 & 17.2 & 21.9 & 22.6 & & 25.0 \\
\hline PSBR (inc. CB profits) & 24.2 & 15.0 & 19.1 & 17.1 & & 19.5 \\
\hline Operational balance & -12.4 & -7.4 & -6.6 & -3.2 & & - \\
\hline Net debt & 61.0 & 58.0 & 58.4 & 78.5 & $(561 / 2)$ & 93.5 \\
\hline Net domestic debt & 40.9 & - & 38.8 & 44.3 & & 53.9 \\
\hline \multicolumn{7}{|l|}{ External sector $^{c}$} \\
\hline Current account balance & -0.7 & -1.5 to -2 & -4.8 & -0.6 & $(-1.5$ to -2$)$ & 1.5 \\
\hline Net external debt & 34.0 & $<34.0$ & 37.0 & 44.3 & & 51.8 \\
\hline
\end{tabular}

Source: IMF (1999a, 2001c, 2002); IMF Press Release No. 01/23, 15 May 2001; real sector performance figures for 2001 are from the Central Bank of Turkey.

a Figures in brackets give the targets set in the original stabilization program of December 1999.

b 12-month, end-of-period.

c In per cent of GNP.

30 percentage points, fiscal sustainability could not be secured without lowering inflation and hence nominal and real interest rates; at the end of the decade the operational deficit of the consolidated public sector, allowing for the inflation component of interest payments, was at an unsustainable level of 12.4 per cent of GDP (table 4). 
The banking system was extremely fragile, as it had been deregulated and granted deposit insurance without effective supervision. It had come to depend on high inflation and high interest rates by lending to the government which had become the single most important borrower in the domestic market: in 1999 total new debt issues by the government were twice as much as total banking sector credits, and interest payments on public domestic debt had come to exceed 15 per cent of GDP. Banks carried relatively large open foreign exchange positions as borrowing abroad and foreign exchange deposits by residents provided important sources of finance for their investment in government paper.

\section{The stabilization program}

The government launched a stabilization program in December 1999 after extensive consultations with the Bretton Woods Institutions, supported by an IMF stand-by credit. ${ }^{6}$ Its target was to bring down the CPI and WPI to 25 and 20 per cent respectively by the end of 2000 , and to the single-digit level by the end of 2002 from projected rates of more than 60 per cent in 1999 (table 4). The inflation target was anchored to a preannounced crawling peg set in terms of a basket made up of the dollar and the euro, with a greater weight accorded to the former. The exchange rate path was announced for the period 1 January 2000 - 31 December 2000. The value of the basket in lira was set to increase by 20 per cent for the year 2000 as a whole (i.e. at the target rate for WPI), at declining monthly rates starting with 2.1 per cent for the first quarter and going down to one per cent for the last three months of the year. At the end of each quarter, the exchange rate schedule was to be extended by three additional months, without altering the part of the exchange rate path already announced. A gradual shift toward a more flexible exchange rate regime would begin in July 2001 with the introduction of a symmetric, progressively widening band about the central exchange rate.

\footnotetext{
${ }^{6}$ For the details of the program see IMF (1999a) and IMF (2000b, box 2.1, p. 46).
} 
This preannounced exit from the peg was considered a major strength of the Turkish program compared to earlier experiments with exchange-rate-based stabilization, particularly in Latin America. Such programs had often been criticized on the grounds that they were launched without adequate attention to the potential problem of real currency appreciation and without a clear exit strategy as to when and how to alter the currency peg or the regime and realign the exchange rate (Eichengreen et al. 1998; and Fischer 2001). Real currency appreciation is not only unavoidable because of stickiness of domestic prices, but more fundamentally, is part of the rationale of successful disinflation, since greater exposure to international trade - resulting in lower real import prices and increased competition in export markets - helps to discipline domestic producers and acts as a break on income claims. Although, economically it may appear simple to restore international competitiveness by a one-off adjustment in the exchange rate, governments are often unwilling to abandon the peg and devalue after exerting considerable effort in attempting to convince people that the peg brought them more good than harm. They are also afraid of losing the confidence of markets and facing a sharp reversal of capital flows and a collapse of the currency. But delaying exit aggravates currency misalignments and external imbalances, eventually making it difficult to engineer an orderly realignment of the exchange rate.

The need to avoid these problems and move away from the soft peg is the main reason why an exit strategy was explicitly built into the Turkish stabilization program (Fischer, 2001, p. 9; and IMF 2000b, p. 48; IMF 2001a, p. 137). However, it was also a gamble on the pace of disinflation: a failure to meet inflation targets could reinforce expectations of a sharp depreciation at the time of the preannounced exit date, risking an earlier attack on the currency. This was, in the event, what happened in Turkey.

The program also provided for a "quasi-currency board" whereby money printing against domestic assets was precluded. For the end of each quarter an upper ceiling was set to the stock of net domestic assets of the central bank at the level reached in December 1999, while some flexibility was allowed within the quarter. As the CBT was committed not to engage in sterilization, macroeconomic equilibrium was to be attained mainly through changes in interest rates: if capital inflows fell short of the current-account deficit, liquidity would be withdrawn from the economy and interest 
rates would rise, thus restoring external equilibrium by attracting more capital, on the one hand, and by restraining domestic demand and imports, on the other.

Fiscal goals included an improvement in the primary balance of the consolidated public sector, to yield a surplus in 2000 to be attained primarily with additional taxation, cuts in current public primary spending, and funds generated by pension reform. This was seen to be sufficient to stabilize the public debt-to-GDP ratio over the medium term. However, disinflation was expected to result in a temporary rise in the burden of interest payments, as a proportion of GDP, on previously issued fix-rate securities, and revenues from privatization were to provide the resources needed to keep the public-debt-to-GDP ratio at its 1999 level.

All these were to be supported by incomes policy and upfront structural reforms. Salary increases for civil servants were to be set in line with the inflation target for the first six months, but would be fully adjusted subsequently for any excess inflation over the target, implying indexation to past inflation. Rationalization of agricultural policies and the pension system, improvement in fiscal management and tax administration, privatization of state-owned enterprises, including in particular Turk Telekom, and strengthening of the banking system and banking regulations were among the structural reforms agreed with the IMF.

\section{Crisis mark I}

In the event, during the course of 2000 the targets for the nominal exchange rate, net domestic assets and primary budget deficits were all attained, but prices proved to be stickier than expected. The CPI inflation on a year-to-year basis started to fall steadily after February 2000, but the pace was slow and the end-year target was overshot by some 15 percentage points. At the end of December 2000, the year-to-year change in the CPI was 39 per cent while the average inflation for the year as a whole reached 55 per cent compared to 65 per cent in the previous year. Given that the predetermined path for the nominal exchange rate had been followed, this resulted in a significant appreciation of the currency in real terms. This was also aggravated by the rise of the dollar against the euro. 
By the standards of other recent exchange-rate-based stabilization programs the Turkish inflation target did not look overambitious. For instance in nine such programs implemented between 1985 and 1998 in a number of countries, at the end of the first year the inflation rate was reduced, on average, to one quarter of its initial level (IMF, 2001a, figure 4.7, p. 137). In the Mexican program, the inflation rate fell from over 110 per cent to 20 per cent after one year. Under the plano real Brazil reduced inflation from an almost four digit level in 1994 to around 22 per cent in 1995. In most of these cases, as in Turkey, there was considerable inertia as inflation had lasted for several years. In Turkey, a number of additional factors account for the relative rigidity of inflation. First, a trade-off emerged between fiscal adjustment and inflation since reducing losses of state owned enterprises required increases in their prices. Secondly, wage increases in the public sector often exceeded the inflation target by a large margin as a result of implementation of collective agreements reached in previous years while in the private sector wage settlements continued to be based on backward indexation. Finally, certain components of CPI, notably rents, rose much faster than the inflation target.

Interest rates fell significantly faster than the rate of inflation, and indeed much faster than expected, even though they were highly volatile: annualized rates on 3-month T-bills averaged around 38 per cent in January-November 2000, compared to over 100 per cent in 1999. The average T-bill real interest rate was negative both in "forward-looking" and "backward-looking" terms (table 4). This was greeted with enthusiasm since earlier attempts at stabilization had failed to lower interest rates despite some success in disinflation (IMF, 2000b, p. 46). The sharp drop in interest rates brought considerable relief to the budget and played an important role in restraining debt accumulation. The improvement in the budget was very impressive, with the primary surplus reaching 2.8 per cent of GDP against a target of 2.2 per cent. Although the government faced constitutional and political difficulties in the privatization of Turk Telekom, ${ }^{7}$ privatization proceeds reached $\$ 3.2$ billion or 1.5 per cent of GDP (IMF 2001a, table 3, p. 36) against a target of 3.6 per cent. This, together with the decline in

\footnotetext{
${ }^{7}$ There was some ambiguity regarding the role that privatization of Turk Telekom was to play in stabilization. On a question on the implication of a failure to do so, the IMF responded that "privatization is not a condition per se in the program. The policy implementation to make privatization possible is a condition. We clearly recognize the difficult environment both in terms of within Turkey but also the world market in telecom, so that we clearly do recognize that as a problem”, IMF, Transcript of a Press Briefing by Thomas Dawson, February 15, 2001.
} 
interest rates and the sharp improvement in the primary budget balance, was sufficient to cut the operational deficit as a proportion of GDP by a large margin and stabilize, and in fact reduce, the public debt ratio (table 4).

There was a fine balance between interest rates and capital inflows throughout the first three quarters of 2000. While capital inflows helped to lower interest rates through the policy of nonsterilization, the latter were nevertheless high enough to create considerable international arbitrage opportunities, since the nominal depreciation of the currency, targeted at some 20 per cent for the year as a whole, fell far short of the differentials with foreign interest rates; the interest rate in dollar terms on investment in government paper was close to 15 per cent for the first 11 months of the year. Consequently, until the crisis broke out in November, private capital inflows and large-scale foreign borrowing by the Treasury were more than sufficient to meet the growing current-account deficit, resulting in a large increase in international reserves which reached some $\$ 24$ billion, exceeding the yearend target of the program. Under the policy rule of non-sterilization, this meant a considerable expansion of domestic liquidity; net external assets of the CBT increased by 53 per cent and the monetary base by 46 per cent between February and mid-November. This, together with the shift in government borrowing from domestic to international markets, helped to lower interest rates, thereby supporting aggregate demand.

The economy enjoyed a positive net capital flow of $\$ 12.5$ billion during the first 10 months of 2000 on account of a large net inflow by nonresidents which financed not only the mounting current account deficits, but also net outflows by residents and increases in reserves (table 3). Strong support given by the BWIs to the stabilization program and expectations of an IMF bailout in case of trouble appear to have played an important role in encouraging lending and investment by non-residents. By contrast, there was a net acquisition of assets abroad by residents, suggesting that despite large return differences, they were reluctant to concentrate their asset holdings in the country. Similarly, forex deposits held by residents in domestic banks rose both in absolute terms and as a share in total commercial deposits. While interest rates on forex deposits remained broadly unchanged at double digit levels (averaging around 10-13 per cent according to maturity, see TCMB, 2001, pp. 37-38), there was a sharp drop in rates on lira deposits. Although the difference was much greater than the 
preannounced rate of depreciation of the currency, the Turkish savers were reluctant to undo their forex deposits and shift to lira and, unlike financial intermediaries, to take the consequent exchange rate risk.

Over 90 per cent of net capital inflows by non-residents were debt-creating, with FDI and portfolio inflows adding no more than $\$ 1.5$ billion out of $\$ 15.2$ billion of net private capital inflows. Three items constituted more than 80 per cent of total net capital inflows; international bond issues by the public sector ( $\$ 5.7$ billion), short-term bank credits from abroad ( $\$ 3.6$ billion), and long-term bank credits ( $\$ 3.2$ billion). Since investment and lending in domestic currency by non-residents were a small proportion of total net capital inflows, currency risk was borne largely by borrowers.

An important part of these risks were concentrated in commercial banks. Just before launching the stabilization program, the government had lowered the upper limit of banks' open forex position to 20 per cent of their equity. Banks could exceed this limit subject to a reserve requirement of 8 per cent in the form of a deposit at the Central Bank. The reserve requirement was raised to 100 per cent in June 2000 in order to eliminate open positions. However, these requirements were not effectively implemented. While reserves effectively held in June 2000 under these provisions implied an underlying open position of some $\$ 2.5$ billion, in reality the figures are said to have been several times greater as banks continued in arbitraging between international markets and Turkish T-bills without obeying the provisions in respect of open positions (Uygur 2001).

Disinflation, currency appreciation and exceptionally low real interest rates combined to generate a strong domestic-demand led recovery in much the same way as in most episodes of exchange-rate-based stabilization programs, with GDP rising by more than 7 per cent in 2000 after a sharp contraction in the previous year. Buoyant economic conditions in turn helped to foster confidence in the stabilization program. There was a surge in gross fixed capital formation, which rose by more than 16 per cent, while private consumption largely kept pace with income growth (OECD, 2001, p. 135). Together with the appreciation of the currency and a rising oil import bill, this led to a surge in imports which increased by 35 per cent in 2000 , while export growth remained at 7 per cent. The trade deficit doubled to more than $\$ 20$ billion, pushing the current-account deficit to an unprecedented 5 per cent of GDP, about three times the level targeted in the program. 
Clearly, the rise in international reserves, strong as it was, would not have been sufficient to sustain external payments in the event of an interruption of capital inflows. While at the beginning of the year reserves were just enough to cover short-term external debt, at the end of the year short-term debt exceeded reserves by 50 per cent, similar to the figure in Thailand on the eve of the 1997 crisis. Again, the ratio of the current-account deficit to reserves rose from 10 per cent to 50 per cent during the same period.

Thus, the Turkish exchange-rate-based stabilization program followed a familiar path with a surge in capital inflows, an upturn in economic activity, a significant appreciation of the currency, mounting trade deficits, worsening balance sheets and rising exchange rate risks. However, compared to most other recent exchange-rate-based stabilization programs that also ended in crashes, in Turkey the boom in capital inflows lasted much shorter and the crisis broke out before any significant progress could be made in disinflation. On the eve of the outbreak of the November 2000 crisis, the inflation rate had come down only to 44.5 per cent on a yearly basis, from a level of 64 per cent a year earlier. While the decline in inflation continued throughout the next three months, the year-to-year consumer inflation was 33 per cent when the peg was finally abandoned in February 2000. By contrast, in Mexico, for instance, the boom in capital inflows lasted several years and inflation had been brought down to a single-digit level by the time the bust came in December 1994. This was also true for the Brazilian program launched in July 1994 to overcome hyperinflation; despite the contagion from East Asia the bust came in January 1999 when inflation had come down to some 6 per cent. Similarly, the Russian program of July 1995 under a crawling peg kept the currency under control and brought inflation down from 225 per cent to some 20 per cent before the outbreak of the crisis in August 1998. ${ }^{8}$

\footnotetext{
${ }^{8}$ For description and comparison of various boom-bust cycles and exchange-rate-based stabilization programs, see
} 
UNCTAD(1995, chap. II; 1999, chap. III; and 2000 chap. IV); Mussa et al. (2000, appendix III); and IMF (2001a, chap. IV). 
As in most emerging-market crises, it is difficult to identify a single event behind the collapse of confidence and flight from domestic assets that occurred in November 2000. The first signs of trouble came in September when net capital flows turned out to be negative mainly on account of a relatively large net security acquisition by residents abroad (TCMB 2001, p. 19). The events that eventually led to a rapid exit of capital in November included disappointing inflation results for October, unexpectedly high monthly trade deficits, political difficulties encountered in privatization, worsening relations with the EU, the economic situation in Argentina, and disclosure of irregularities in the banking system and a criminal investigation into several banks taken over by the SDIF. There may also have been a rush to liquidity due to competitive maneuvering among some private banks. ${ }^{9}$ However, quite apart from all this, the program had clearly run into the familiar problems of exchange-rate-based stabilization that relies on arbitrage flows. As confidence eroded, foreign creditors refused to roll over their contracts with local banks or sold assets to exit. In November 2000 withdrawal of capital by nonresidents is estimated to have exceeded $\$ 5.2$ billion, which was fully reflected in the depletion of international reserves in the last two weeks of November. For their part, domestic banks sold liras in an effort to reduce their end-of-year open positions. The exit from the lira created difficulties for banks relying on foreign funds and resulted in a liquidity crunch and a hike in interest rates by draining international reserves. Banks carrying large T-bill portfolios with funds borrowed in overnight markets suffered significant losses and started to bid for funds in the interbank market, at the same time unloading large amounts of government paper. Within a few days stock prices plummeted, rates on benchmark T-bill rose from 35 per cent to 50 per cent and overnight rates reached three-digit levels. The CBT faced the classical dilemma posed by loss of confidence under currency-board regimes: either to defend the monetary rule and, ultimately, the currency peg at the expense of a deep financial crisis, or to act as a lender of last resort and rescue the financial system by injecting liquidity over and above its net

\footnotetext{
${ }^{9}$ On some accounts the crisis was triggered because a number of banks pushed up the interbank rate in a competitive manoeuvring with their rival, Demirbank, forcing it to unload substantial amounts of T-bills and creating a break in market liquidity and putting pressure on interest rates. For a view from financial markets on the possible contribution of various factors to the outbreak of the crisis in Turkey see JP Morgan (2000).
} 
domestic asset targets. After some hesitation it started supplying liquidity to troubled banks. But this only served to accelerate the erosion of international reserves as the sale of liras on the foreign exchange market accelerated. Thus, the injection of liquidity did not prevent a contraction in the monetary base.

Within a few days the CBT reversed its policy and, evidently after the insistence of, and securing commitments from, the IMF, reinstated the currency-board rule with a new ceiling on domestic assets. As liquidity injection was discontinued and reserves were still sufficient to meet short-term external liabilities, capital outflows stopped, but interest rates shot up with overnight rates reaching fourdigit levels. At the beginning of December a new agreement was reached with the IMF, including a financial package of some $\$ 10.5$ billion, including $\$ 7.5$ billion, or 600 per cent of Turkey's quota in the IMF, from the Supplemental Reserve Facility. The government undertook fresh commitments, including further spending cuts and tax increases, the dismantling of agricultural support policies, liberalization of key goods and services markets, financial sector restructuring and privatization. It also extended guarantees for foreign creditors as well as for all depositors of local banks in order to help restore confidence in the banking system. ${ }^{10}$

\section{Crisis mark II}

The IMF support and new commitments by the government appeared to stabilize the currency and financial markets at the end of 2000, halting capital outflows. By mid-January international reserves had been replenished, exceeding their pre-crisis level, and interest rates had fallen below 60 per cent. Imports slowed with the weakening of aggregate demand, and inflation continued to fall even though it remained at twice the rate of the crawl. Even in the middle of the November crisis the IMF appeared fully confident that the program was working:

\footnotetext{
${ }^{10}$ This move appears to have had the full support of the Managing Director of the IMF: "I particularly welcome the government's firm commitment to implement a bold set of measures to strengthen the soundness of the banking sector aimed at tackling the root causes of the current problems. I welcome the firm action already taken in this respect, including the decision to protect depositors and other creditors in Turkish banks", IMF, News Brief No. 00/113, December 6, 2000.
} 
The disinflation and fiscal adjustment program launched by the Turkish government in late 1999 has achieved important results: inflation this year will be the lowest since the mid-1980s; growth has picked up strongly; and public indebtedness, which was rising steeply in relation to GDP last year, is now falling. ... In sum, the program is on track, and it is expected to remain so given the authorities' strong policies for 2001 (Fischer). ${ }^{11}$

And subsequent commitments and measures reaffirmed this confidence:

${ }^{11}$ IMF's Fischer says Turkey Program on Track, IMF News Brief No. 00/17, November 26, 2000. 
Policy implementation since the last Executive Board meeting has been most encouraging. In particular, the central bank has strictly implemented the monetary policy framework laid out in December 2000 Letter of Intent and important actions in the structural area have been implemented during January (Kohler). ${ }^{12}$

However, because of the underlying weaknesses, stability proved short-lived and it became increasingly clear that the program was not viable. While external funds remained invested at extremely short maturity, from late January there was increasing recourse to auctioning T-bills with shorter maturities, and interest rates started to shoot up, reaching 70 per cent in mid-February. These developments cast serious doubts on the sustainability of public debt, and exposed banks with large portfolios of government bonds with maturities of 12-18 months purchased at low interest rates during 2000. Rising public debt, high inflation and the continued real appreciation of the currency created considerable uncertainty over the sustainability of the peg. It took a political skirmish between the Prime Minister and the President to break the peg in the second half of February 2001. Massive flight from the Turkish lira could not be checked despite rising interest rates, with overnight rates reaching 5,000 per cent and liquidity drying up. Since the attack on the currency threatened complete loss of control over monetary policy as well as a rapid depletion of international reserves, the government was forced to abandon the peg and to float the currency, again with the support of the IMF. ${ }^{13}$ Within a single day the currency lost about one-third of its value against the dollar with the exchange rate falling from TL 680 thousand per dollar to TL 960 thousand.

\footnotetext{
${ }^{12}$ IMF News Brief No. 10/13, February 5, 2001.

${ }^{13}$ On some accounts the IMF had wanted to move to floating in November but this was opposed by the government for fear of loss of credibility.
} 
Despite a sharp turnaround in the current-account balance brought about by the collapse in economic activity and the freeing of the central bank from its obligation to defend the currency peg, reserves fell drastically as a result of a rapid exit of capital - some $\$ 6$ billion between the date of the float and the end of September 2001. For the whole period from the outbreak of the November crisis, net capital flows amounted to some - $\$ 17$ billion, in large part on account of exit by non-residents which had to be fully covered from reserves (including borrowing from the IMF), since the current account was also in deficit during that period (table 3). For the entire period from the launching of the stabilization program, the swing in net capital flows reached $\$ 28$ billion, mainly due to boom and bust in investment and lending by non-residents. This amounts to 14 per cent of GDP, compared to some 10 per cent during the Mexican boom-bust cycle. About one-third of this was accommodated by a sharp turnaround in the current account deficit and the rest by changes in reserves.

As the financial turmoil deepened, the economic team was changed and an agreement was reached with the IMF in May 2001 on a new program (the so-called strengthened program), supported by an additional stand-by credit of $\$ 8$ billion, bringing the total IMF credit extended since December 1999 to $\$ 19$ billion. ${ }^{14}$ In addition to structural policies focussing on banking, fiscal transparency and privatization, the program set new macroeconomic targets for the rest of the year as well as for 20022003. Compared to the original targets set for 2001 in the December 1999 program, growth and current account deficit targets were significantly lowered while inflation and public debt targets were raised (table 4, last column). These projections for the year as a whole were based on the assumption that the economy would stabilize and growth would resume in the second half of the year with a decline in inflation and a rebound in export earnings (IMF 2001c, pp. 52-53). All these were predicated on a strong fiscal adjustment, to be brought about primarily by cuts in public employment and investment, while monetary policy was to focus on the control of monetary aggregates subject to a quantitative ceiling on net domestic assets of the CBT and a floor on its net international reserves:

Because of the weakening of economic activity (some 7 percentage points below the original baseline), the primary surplus [in 2001] would be projected to fall to $2 \frac{1}{2} 2$ points of GNP. The new target for 2001 is $5 \frac{1}{2} 2$ percentage points of GNP, requiring the

\footnotetext{
${ }^{14}$ IMF (2001b). For an heterodox critique of the strengthened program see BSBIG (2001).
} 
introduction of additional measures amounting to 3 percentage points of GNP. This is a massive strong effort. Altogether, between 2000 and 2001, the government will have introduced measures amounting to 5 percentage points of GNP (in addition to the almost 5 percentage points of GNP adjustment implemented between 1999 and 2000 (IMF 2001c, p. 18).

While the government was on the one hand trying to stabilize its debt by creating large primary surpluses and converting domestic debt to external debt, it was on the other hand adding to its liabilities by capitalizing the banks taken over by the SDIF and meeting the losses of state banks exposed to mounting interest rates. After the November crisis, the public sector had to issue securities amounting to 2 per cent of GNP to capitalize the banks taken over by the SDIF (IMF 2001c, pp. 7-8, Box 1, p. 10, and table 5, p. 78).

Even though fiscal and monetary performance criteria were generally met throughout the year, stabilization and growth proved elusive. Inflation and interest rates remained well above projections, and the exchange rate continued to overshoot under speculative pressures in a rather thin market, dropping to TL 1.6 million per dollar towards the end of the year as the CBT stood-by and watched, to recover only on the news that the Fund would provide some additional finance. The government only gradually came to grasp the gravity of the situation:

We have revised our macroeconomic projections for 2001 in light of recent data. We now project a fall in real GNP for 2001 as a whole of $5 \frac{1}{2}$ percent, compared with the original program projection of a decline of 3 percent. ... For the whole year, we now expect CPI inflation to be 58 percent, compared with the originally projected 52.5 percent.... The external current account balance is expected to show a US\$5 billion (3 per cent of GNP) surplus for the year (compared with the originally projected broad balance) (IMF 2001d, pp. 1-2).

Again, the program remained on track with respect to its macroeconomic policy performance indicators and structural reforms in the following months, but its growth and inflation targets were off the mark, which forced the government to revise its projections once more:

A steeper-than-expected decline in the second quarter had already suggested a need to revise downward our earlier projection of real GNP growth of -5.5 percent in 2001 . 
The September 11 shock has further delayed the recovery, and we now estimate real GNP to decline by 8.5 percent this year.... As regards inflation, the further currency depreciation suggests that our end-year CPI inflation projection needs to be increased from 58 to 65 percent.... Finally, the economic slowdown and the depreciation of the Turkish lira have led to a marked turnaround in the external current account in 2001, with a surplus of US $\$ 2 \frac{1}{4}$ billion projected for the full year despite the anticipated loss of tourism and export receipts in the last quarter (IMF 2001e, p. 2).

The move to floating under conditions of fiscal imbalances, high inflation and financial fragility has presented serious policy dilemmas. Under the previous regime of crawling peg, while interest rates were allowed to move in response to capital flows, the peg was expected to bring down inflation as well as nominal and real interest rates, and to facilitate fiscal adjustment. As noted above, capital flows helped this process by leading to liquidity expansion under the quasi-currency board rule for the monetary policy. The move to floating under distress effectively removed any control policy may have had over exchange rates, interest rates and inflation. Although the currency was left to "market forces" in order to free monetary policy and interest rates from defending a particular exchange rate, the erosion of confidence in the lira and capital outflows tended to reduce liquidity and to push up the interest rates. The latter development aggravated the fiscal problem and resulted in further loss of confidence.

Thus, a collapse of the currency and a simultaneous hike in interest rates, a combination often observed in emerging markets applying orthodox recipes in response to capital flight, have appeared with greater force in Turkey because of the accompaniment of inflation and fiscal imbalances. There has been little scope for the use of monetary policy to bring down interest rates to provide a stimulus to the economy and to facilitate fiscal adjustment. Not only have there been restraints on monetary expansion owing to a ceiling on net domestic assets and a floor to international reserves, but a move in the direction of monetary relaxation would also raise fears of the monetization of government deficits. Attempts by the CBT to exert some downward influence on interest rates by expanding liquidity though sale of reserves provided by the IMF had very little effect on the T-bill market.

Under these conditions, hopes were pinned on the return of arbitrage capital to stabilize the exchange rate and to bring down interest rates by restoring confidence. In the absence of an effective 
macroeconomic policy, however, emphasis was placed on political commitment to structural change, which created difficulties in the fragile coalition. Again, the IMF became the key player, not only by providing the funds needed to support the fiscal and financial systems, but also the much-needed positive signals to financial markets. Thus, persuaded that implementation of the program was very strong but that the external shock of September 11 had raised the financing gap, the Fund stood ready at the end of 2001 to establish a new stand-by agreement and to provide the country with an additional $\$ 10$ billion for the remainder of 2001 and 2002. This was the fourth bailout package in two years, bringing the total of IMF financing to almost $\$ 30$ billion. $^{15}$

While the Fund bailout package helped stabilize the currency market, much of the impetus also came through the familiar deflationary process. On the one hand, the collapse of economic activity brought a massive turnaround in the balance of payments mainly as a result of a sharp decline in imports: these fell by 26 per cent in 2000 after growing by 35 per cent in the previous year, while export growth remained at a modest 11 per cent, up from 7 per cent in 2000, despite a sharp devaluation of the currency. On the other hand, as debt deflation and recession deepened, many debtors became insolvent and unable to raise funds to purchase foreign exchange to service their debt, thus reducing the sales of domestic currency for foreign exchange. In other words, markets have been stabilized not so much by the influx of foreign capital as by deflation, a liquidity squeeze and an increasing number of defaults.

\section{Accounting for the crisis: omission or commission?}

\footnotetext{
${ }^{15}$ IMF News Brief No. 01/116, November 15, 2001.
} 
As in other recent crises in emerging markets, the IMF has come up with a number of ex post facto explanations for why the crisis broke out and why it has proved so deep, putting the blame on slippages in implementation of the policies agreed as well as on some adverse external developments rather than on the design of the stabilization program or misguided intervention in the crisis. Some examples of such explanations are the following: "The speculative attack on the Turkish lira took place against the background of increased political uncertainty, policy slippages and a weakening of economic fundamentals" (IMF 2001c, p. 2); "The Turkish authorities were initially very effective in implementing the IMF-supported program, but they were less successful in coping with unexpected events such the tripling of oil prices, the strong dollar, rising international interest rates, and an overheating economy" (Cottarelli, 2001); "The recent difficulties in Turkey relate more to banking sector problems, and the failure to undertake corrective fiscal actions when the current account widened, than to the design of the exchange rate arrangement" (Fischer, 2001, p. 9).

These explanations have been challenged by many Turkish economists, including some former senior economists of the BWIs, on grounds that the policies advocated were based on a poor diagnosis of economic conditions in the country and the Fund was experimenting with programs that lacked sound theoretical underpinnings (e.g. Kumcu 2001; and Yenal 2001). It is particularly notable that the program was so designed that there was little policy space left for corrective macroeconomic action in the face of widening current-account deficits. By the time the difficulties became apparent, the 2000 budget had already been finalized according to the deficit targets set in the program, and there was effectively little room either on the spending side or on the revenue side to act rapidly to slow demand expansion. This role could have been achieved by monetary policy, in the absence of the quasicurrency board and non-sterilization rules incorporated in the stabilization program.

There can be little doubt that, given the extent of fiscal profligacy and financial fragility, there was no easy way to stabilize the Turkish economy. However, in many respects the Turkish economy today is in a worse shape than it was on the eve of the December 1999 stabilization program. After two years of "policy reforms", the GNP is now 3 per cent lower than at that date since the 9.4 per cent drop in 2001 wiped out all the gains made during the 2000 boom. Moreover the WPI has reached almost 90 per cent as compared with some 60 per cent in the earlier period, and the public debt has risen to 
more than 90 per cent of GNP from 60 per cent. All targets set for the real sector for 2001, including those revised in the middle of the year, have been missed by a large margin (table 4). The program has failed and the crisis has deepened in large part because of serious shortcomings in its design and implementation as well as in crisis management.

Anyone who was familiar with the Turkish banking system and the dynamics of the exchangerate-based stabilization programs could have anticipated the risks entailed by a rapid decline in interest rates as well as the vulnerability of the economy to boom-bust cycles in capital flows. Certainly countries such as Brazil have been successful in exchange-rate-based stabilization despite large fiscal imbalances, but in such cases the banking system had undergone an extensive restructuring and strict supervisory and regulatory provisions had been introduced well in advance (UNCTAD 1999, chap. III). Again, one of the lessons from East Asian crisis was that the worst time to "reform" a financial system is in the middle of a crisis (UNCTAD 1998, p. iii). Overhauling the banking system before launching the stabilization program would have helped greatly to avoid many of these difficulties. ${ }^{16}$ However, these lessons appear to have been overlooked both in the design of the stabilization program and crisis intervention.

Furthermore, a careful examination of recent experiences with soft-pegs and exchange-ratebased stabilization programs shows that many of the weaknesses in economic fundamentals, including currency appreciation, deterioration of the current account, and increased exposure to exchange-rate risk, often result from the effects of capital inflows themselves rather than from policy slippages (UNCTAD 1998, chap. III). Such episodes are often characterised by an upturn in economic activity and a surge in imports, financed by inflows of arbitrage capital. In Turkey both the Fund and the government were quite happy to see that the economy was making a strong upturn in 2000 after a deep recession in 1999, and they were not willing to discourage the capital inflows underlying this process. As already noted, reserve requirements introduced to discourage open positions were not implemented

\footnotetext{
${ }^{16}$ Before the stabilization program was launched in December 1999, one of the authors of this paper had urged that priority should be given to legal and institutional arrangements in order to reform the banking system and social security institutions, and in order to bring fiscal discipline before attacking inflation; see Söyle_i/Yilmaz Akyüz, “Türkiye’nin isi zor!”, Power, July 1999. See also Milliyet, 6 June 1999.
} 
effectively. More generally, although after the recent bouts of financial crises the Fund has willy-nilly admitted that some such market-based restrictions over arbitrage flows (including the Chilean-type reserve requirements) could be useful, it has never actually encouraged developing countries to check such flows even when it was clear that they could not be sustained over the longer term. On the other hand, experience shows that even countries with strict fiscal discipline have not always been able to pursue counter-cyclical policies at times of massive capital inflows to prevent overheating and currency appreciation, and the room for such policies was much more limited in Turkey owing to the size of initial fiscal imbalances and the extent of retrenchment already incorporated in the stabilization program. On the other hand, as noted above, monetary policy was excluded from playing this role by currency-board and non-sterilization rules.

Regarding external factors it is true that the decline of the euro against the dollar created difficulties for Turkish exports. Nevertheless, as already noted, export performance was quite satisfactory, with earnings rising by 7 per cent in 2000 and thus broadly keeping pace with growth in world trade. In any case, according to the Fund's own judgment discussed above, the appreciation of the lira should not have caused a major problem since the currency was estimated to have been undervalued by some 10 per cent on the eve of the stabilization program, and the subsequent appreciation was in the same order of magnitude.

The policy response to the speculative attack on the currency was broadly the same as in previous emerging market crises. The IMF provided funds in order to guarantee repayment of foreign creditors and to ensure the maintenance of convertibility of the lira and free capital movements, while also promoting tight macroeconomic policies and structural reforms to restore confidence in financial markets. Doubtless, there are of course always some variations around the basic theme. The Fund was quick in demanding a move to floating in large part because of increased criticisms from the United States congress that its interventions resulted in using taxpayers' money to defend unsustainable exchange rates and policies, and because the Thai, Korean, and Brazilian experiences had clearly shown that, as long as capital is free to move, currency pegs cannot be maintained or realigned in an orderly way once confidence is eroded. ${ }^{17}$ However, these nuances in the Fund's approach to the Turkish crisis

\footnotetext{
${ }^{17}$ The IMF's bail-outs in Thailand and Republic of Korea were rendered more difficult by lack of transparency regarding the two countries' levels of usable foreign currency reserves. In the case of Thailand most of the country's
} 
did not make much difference for the final outcome: the policies advocated failed to restore confidence, the currency collapsed, interest rates skyrocketed, and the economy went into an unprecedented recession in the postwar era.

reported total reserves had in fact been committed for future delivery in forward transactions undertaken as part of efforts to defend the exchange rate. In the case of Republic of Korea much of the country's reported reserves had been deposited in the overseas branches and affiliates of its banks to help them to meet obligations on maturing foreign-currency debts. Speedy withdrawal of these deposits would have threatened the stability of the banking system. In Brazil the 1998 program with the IMF had stipulated an orderly exit from the peg through gradual devaluations throughout 1999 as well as emergency financing, but in this case an orderly exit was rendered impossible by pressures on the currency in the wake of the Russian crisis. 
During the East Asian crisis there was a widespread criticism of Fund conditionality, including from some mainstream economists (e.g. Feldstein 1998), on the grounds that it was intrusive, often resulting in unnecessary interference with the proper jurisdiction of a sovereign government. Subsequently, the International Monetary and Financial Committee recognized the need to streamline IMF conditionality, and urged "the Executive Board to take forward its review of all aspects of policy conditionality associated with Fund financing in order to ensure that, while not weakening that conditionality, it focuses on the most essential issues". ${ }^{18}$ For his part, the Fund's new Managing Director, Horst Köhler, has likewise concluded that to "strengthen its efficiency and legitimacy, the Fund needs to refocus. The Fund's focus must clearly be to promote macroeconomic stability as an essential condition for sustained growth. To pursue this objective, the Fund has to concentrate on fostering sound monetary, fiscal and exchange rate policies, along with their institutional underpinning and closely related structural reforms". ${ }^{19}$ However, the Fund policies in Turkey have shown no significant tendency to depart from past practice. Indeed, as it became clear that the program was no longer viable, the Fund started to harden its position in an effort to shift a greater share of the responsibility onto the government, interfering in such matters as appointments in public bodies, an action which created conflicts within the coalition government. As in Indonesia, this proved to be counterproductive, eroding further the confidence that the Fund and the government were desperately seeking to reestablish, and thus deepening the crisis.

\footnotetext{
${ }^{18}$ Communiqué of the International Monetary and Financial Committee of the Board of Governors of the International Monetary Fund, 24 September 2000, Washington, DC: para. 11.

${ }^{19}$ Horst Köhler, Address to the Board of Governors, Fifty-fifth Annual Meeting, Prague, 26 September 2000.
} 
Both the stabilization program and the subsequent crisis intervention in Turkey were designed to overcome instability and excessive indebtedness, while meeting fully the claims of the creditors. Unlike in East Asia, however, the latter included domestic lenders to the Turkish government. Indeed, the Turkish debt problem, in so far as it relates to macroeconomic instability, is predominantly an internal one. However, the economy has also been facing difficulties in rolling over its external debt which has reached $\$ 120$ billion or 80 per cent of GNP in current dollars. A large proportion of this was incurred in the past decade not so much to finance current-account deficits - which, as noted above, had remained moderate until the new millennium - as to meet net capital outflows by residents that accelerated after the liberalization of the capital account. Much of the IMF funding has been used to pay foreign private liabilities, notably of banks, and to cover the withdrawals of foreign portfolio investors. This has in effect allowed the government to translate part of its domestic debt into external liabilities to the IMF.

\section{Standing still and moving forward}

Much has been written on possible solutions to the problem of internal debt, but no one has done so more forcefully and with greater persuasiveness than did Keynes in his analysis of what he called "progressive and catastrophic inflations" in Central and Eastern Europe during the early 1920s (see Annex). Thus, borrowing his terms, the Turkish government has been demanding sacrifices from "the active and working elements" of the society in order to be able "to hand over to the rentier or bond-holding class" a large portion of "the fruits of their work" (the entire tax revenues in 2001), refusing to seek relief in some other ways including "in one or other of two out of the three possible methods" favoured by Keynes.

For obvious reasons neither monetization nor a capital levy nor any other measure that would place a sizeable burden on the rentier class can be successfully applied when the capital account is open and the domestic currency is fully convertible. In other words, the conditions that make it difficult to manage the external value of the currency also aggravate the difficulties in managing internal debt. Consequently, temporary suspension of convertibility and standstills on external debt payments are a practical (and in some cases probably the only practical) policy option for stabilizing the exchange rate 
in countries facing international liquidity problems and for an orderly workout of external and domestic debt.

These measures have long been advocated by the UNCTAD secretariat drawing on the rationale and key principles for an orderly debt workout as found in domestic bankruptcy procedures, most notably chapter 11 of the United States Bankruptcy Code, in order to overcome the difficulties associated with official bailouts and crisis intervention. ${ }^{20}$ The rationale for such a temporary standstill is based on the recognition that a grab race for assets by creditors is not only detrimental to the debtor but also to the creditors themselves as a group. The combination of official bailouts and policies advocated to restore confidence, including fiscal and monetary tightening, often fail to check the asset grab race and capital flight and the resulting collapse of the currencies (as was exemplified in the financial crises of a number of countries in recent years). Furthermore, bailouts create moral hazard for lenders and shift the burden onto debtor countries and their taxpayers, who ultimately pay off the official debt. The principle of bailouts is also difficult to reconcile with the rationale of free markets since it is generally agreed that market discipline will work only if creditors bear the consequences of the risks they take.

Recognizing these difficulties UNCTAD economists have proposed that "a credible strategy for involving the private sector in crisis resolution should combine temporary standstills with strict limits on access to Fund resources" (UNCTAD 2001, p. 140). Standstills on sovereign debt involve suspension of payments by governments themselves, while on private external debt they require the imposition of temporary exchange controls which restrict payments abroad on specified transactions, including interest payments. Further restrictions may also be needed on the capital-account transactions of both residents and non-residents.

\footnotetext{
${ }^{20}$ This proposal was first made in the context of the debt crisis in the 1980s (UNCTAD, 1986, annex to chap. IV), and more recently in relation to emerging-market crises (UNCTAD, 1998, pp. 89-93). For a detailed description of these principles, the problems with bailouts and IMF intervention in crises and the state of the debate on involving the private sector in crisis resolution see Akyüz (1999 and 2002) and Akyüz and Cornford (1999).
} 
Although the IMF Board has recognized that countries may find it necessary, as a last resort, to impose a unilateral standstill, it has not been able to provide statutory protection to debtors in the form of a stay on litigation because of strong opposition from some of the major economic powers and market participants. Governments in some debtor countries, notably in Latin America as well as in Turkey, have also been reluctant to back this proposal for fear of impairing their access to international capital markets. However, in view of the difficulties encountered in implementing voluntary workouts for the Argentinian debt and the failure of IMF interventions to stabilize Argentina and Turkey, together with the economic difficulties faced in industrial countries themselves, international bankruptcy codes and standstills have been getting a fuller hearing. Following the recent endorsement of the general idea by the United States Treasury secretary, the IMF now appears to be moving in the direction of establishing some international debt workout procedures. Its First Deputy Managing Director has recently described the new approach in the following terms:

A formal mechanism for sovereign debt restructuring would allow a country to come to the Fund and request a temporary standstill on the repayment of its debts, during which time it would negotiate a rescheduling with its creditors, given the Fund's consent to that line of attack. During this limited period, probably some months in duration, the country would have to provide assurances to its creditors that money was not fleeing the country, which would presumably mean the imposition of exchange controls for a temporary period of time....

Sovereign debt owed to domestic residents may well need to be included in any restructuring for three reasons. First, in the absence of capital controls, balance of payments problems are as likely to arise from the flight of domestic investors and lenders as from withdrawal of foreign ones. Second, domestic debt may impose an unsustainable fiscal burden, especially as the crisis will already be weakening the country's budgetary position by depressing economic activity. Third, external creditors are less likely to agree to a reduction in the value of their own claims if they know that domestic investors are simultaneously being repaid in full or in much greater proportion.

The stay might also apply also to foreign debts owed by nonsovereign residents. This is because of problems created by the use of exchange controls to protect foreign exchange reserves. A company that is relatively unaffected by the crisis ... may suddenly find itself vulnerable to litigation because exchange controls might prevent it paying its overseas creditors during the periods of stay.(Krueger, 2001, pp. 7. 9). ${ }^{21}$

\footnotetext{
${ }^{21}$ There are some differences between UNCTAD and IMF proposals. In the UNCTAD proposal the decision to impose standstill should rest with the debtor country but would then be subject to an examination and endorsement of an independent panel very much along the lines of the WTO safeguards procedures. UNCTAD proposal also includes strict limits on crisis lending. In the IMF proposal, the "standstill would be activated if a request by the
} 
This, in effect, amounts to a recognition that the approach so far adopted in official intervention in emerging market crises, built on the principle of maintenance of open capital accounts and convertibility and guaranteed repayment to creditors, may not always be successful in stabilizing the markets and avoiding costly crises. Indeed, as discussed above, this has certainly been the case in Turkey. But, even if orderly debt workouts become part of the international financial architecture, for Turkey present difficulties will have to be resolved under existing rules:

A number of our members have expressed a desire to move in this direction. We look forward to discussing our ideas with the Fund's Executive Board next month. But even with unanimous political support this approach could not be in place for at least two or three years. So none of what I have to say tonight has implications for our current negotiations with member countries - Argentina and Turkey, for example (Krueger 2001, pp. 1-2). 


\section{Annex : Keynes on Debt and Inflation}

In writing on what he called "progressive and catastrophic inflations" in Central and Eastern Europe during the early 1920s, Keynes characterized the debt problem and possible solutions to it in the following terms:

The active and working elements in no community, ancient or modern, will consent to hand over to the rentier or bond-holding class more than a certain proportion of the fruits of their work. When the piled-up debt demands more than a tolerable proportion, relief has usually been sought in one or other of two out of the three possible methods. The first is repudiation. But except as the accompaniment of revolution, this method is too crude, too deliberate, and too obvious in its incidence. The victims are immediately aware and cry out too loud; so that, in the absence of revolution, this solution may be ruled out at present, as regards internal debt, in Western Europe.

The second method is currency depreciation? The owners of small savings suffer quietly, as experience shows, these enormous depredations, when they would have thrown down a Government which had taken from them a fraction of the amount by more deliberate but juster instruments ? It follows the line of least resistance, and responsibility cannot be brought home to individuals. It is, so to speak, nature's remedy, which comes into silent operation when the body politic has shrunk from curing itself.

The remaining, the scientific, expedient, the capital levy, has never yet been tried on a large scale; and perhaps it never will be. It is the rational, the deliberate method. But it is difficult to explain, and it provokes violent prejudice by coming into conflict with the deep instincts by which the love of money protects itself ? Once currency depreciation has done its work, I should not advocate the unwise, and probably impracticable, policy of retracing the path with the aid of a capital levy. But if it has become clear that the claims of the bond-holder are more than the taxpayer can support, and if there is still time to choose between the policies of a levy and of further depreciation, the levy must surely be preferred on grounds both of expediency and of justice.

There is a respectable and influential body of opinion which, repudiating with vehemence the adoption of either expedient, fulminates alike against devaluations and levies, on the ground that they infringe the untouchable sacredness of contract; or rather of vested interest ? Yet such persons, by overlooking one of the greatest of all social principles, namely the fundamental distinction between the right of the individual to repudiate contract and the right of the State to control vested interest, are the worst enemies of what they seek to preserve. For nothing can preserve the integrity of contract between individuals, except a discretionary authority in the State to revise what has become intolerable. The powers of uninterrupted usury are too great. If the accretions of vested interest were to grow without mitigation for many generations, half the population would be no better than slaves to the other half.

These conclusions might be deemed obvious if experience did not show that many conservative bankers regard it as more consonant with their cloth, and also as economising thought, to shift public discussion of financial topics off the logical on to an alleged 'moral' plane, which means a realm of thought where vested interest can be triumphant over the common good without further debate. But it makes them untrustworthy guides in a perilous age of transition. When? we enter the realm of State action, everything is to be considered and weighed on its merits. Changes in death duties, income tax, land tenure, licensing, game laws, church establishment, feudal rights, slavery, and so on through all ages, have received the same denunciations from the absolutists of contract, who are the real parents of revolution (Keynes, 1971, pp. 53-55). ${ }^{22}$

\footnotetext{
${ }^{22}$ The political difficulties of introducing a capital levy, Keynes' preferred instrument for dealing with a debt overhang, are exemplified by the eventually abortive attempt of another famous twentieth-century economist, Joseph Schumpeter, during his seven-month tenure as Minister of Finance in Austria in 1919 (Stolper 1994, Part IV).
} 


\section{REFERENCES}

Akyüz, Y. and A. Cornford (1999). "Capital Flows to Developing Countries and the Reform of the International Financial System", UNCTAD Discussion Paper, No. 143, November.

Akyüz, Y. (2000). "The Debate on the International Financial Architecture: Reforming the Reformers", UNCTAD Discussion Paper, No. 148, April.

Akyüz, Y. (2202). "Crisis Management and Burden Sharing”, in Y. Akyüz (ed.), Reforming the Global Financial Architecture: Issues and Proposals, Zed Books.

Aricanli, T. and D. Rodrik eds. (1990). The Political Economy of Turkey, London, Macmillan.

Boratav, K. and E. Yeldan (2001). "Turkey, 1980-2000: Financial Liberalization, Macroeconomic Instability and Patterns of Distribution", mimeo, CEPA, New School, December.

BSBIG (Ba_ms_z Sosyal Bilimciler_ktisat Grubu) (2001). Güçlü Ekonomiye Geçi_Pro_ram_ Üzerine De_erlendirmeler, Türk Mühendis ve Mimarlar Odalar_Birli_i, June.

Cottarelli, C. (2001). Turkey Always had Control of its Economy, Financial Times, June 5.

Eichengreen, B., P. Masson, H. Bredenkamp, B. Johnston, J. Hamann, E. Jadresic, and I. Otker (1998). Exit Strategies. Policy Options for Countries Seeking Greater Exchange Rate Flexibility. IMF Occasional paper, No. 168.

Feldstein, M. (1998), "Refocussing the IMF”, Foreign Affairs, vol. 77, No. 2 (March/April).

Fischer, S. (2001). Exchange Rate Regimes: Is the Bipolar View Correct?", New Orleans, American Economic Association, January.

IMF (1999a). Turkey. Letter of Intent, December 9.

IMF (2000a). Turkey: Selected Issues and Statistical Appendix. Staff Country Report No. 00/14, November.

IMF(2000b). World Economic Outlook, May.

IMF (2001a). World Economic Outlook, May.

IMF (2001b). IMF Approves Augmentation of Turkey’s Stand-By Credit to US\$19 Billion, Press Release No. 01/23, May 15.

IMF (2001c). Turkey: Sixth and Seventh Reviews Under the Stand-By Arrangement. IMF Country Report No. 01/89, June.

IMF (2001d). Turkey. Letter of Intent, Memorandum of Economic and Financial Policies, and Technical Memorandum of Understanding, July 31.

IMF (2001e). Turkey. Letter of Intent. November 20.

IMF (2002). Turkey: Tenth Review Under the Stand-By Arrangement. IMF Country Report No. 02/21, February.

JP Morgan (2000). "Data Watch: Turkey”, Global Data Watch, November-December (various issues).

Keynes, J.M. (1971). "Public finance and changes in the value of money", chap. 2 of A Tract on Monetary Reform in The Collective Writings of John Maynard Keynes, vol. IV, Cambridge University Press. 
Krueger, A. (2001). International Financial Architecture for 2002: A New Approach to Sovereign Debt Restructuring, Address given at the National Economists' Club Annual Members' Dinner, American Enterprise Institute, Washington, DC, November 26.

Kumcu, E. (2001). The IMF’s blunder in Turkey, Financial Times, March 13.

Mussa, M., P. Masson, A. Swoboda, E. Jadresic, P. Mauro, and A. Berg (2000). Exchange Rate Regime in an Increasingly Integrated World Economy, IMF Occasional Paper, No. 913, 2000.

Stolper, W.F. (1994), Joseph Alois Schumpeter: The Public Life of a Private Man, Princeton University Press.

TCMB (The Central bank of the Republic of Turkey) (2001). Quarterly Bulletin No. II, April- June.

OECD (2001). Economic Outlook, No. 69, June.

UNCTAD (1995-2001). Trade and Development Report, Geneva.

UNCTAD (2001a). Global Economic Trends and Prospects. An Update, October 2001, Geneva.

Uygur, E. (2001). “Krizden Krize Türkiye: 2000 Kas_m and _ubat Krizleri”, mimeo, Ankara University, SBF, March. Yenal, O. (2001). The irresponsible monetary fund, Financial Times, July 12. 